\title{
Investigating inhibitor influence on pickling tin metal resist from copper conductors of printed circuit boards
}

\author{
Yu.I. Kapustin, A.G. Kholodkova and T.A.Vagramyan \\ D. Mendeleev University of Chemical Technology of Russia, Miusskaya sq. 9, 125047 \\ Moscow, Russian Federation \\ E-mail: tvagramyan@muctr.ru
}

\begin{abstract}
The inhibitor influence on nitric acid pickling printed circuit boards for removing the tin metal resist from copper conductors has been investigated. The proposed pickling solution has high selectivity in solving galvanic tin as compared to copper and it can be corrected easily.

Received: October 9, 2017. Published: December 8, 2017

doi: $\underline{10.17675 / 2305-6894-2018-7-1-1}$
\end{abstract}

Key words: inhibitors; printed circuit boards; tin metal resist; pickling solution; nitric acid.

\section{Introduction}

The process technology for treating foil-coated dielectrics in making printed circuit boards involves the stage of removing the metal resist. A film of copper alloy and tin is formed at the interphase boundary on covering the metal copper surface with the thin tin layer, in time its thickness increasing gradually.

So, it is necessary to remove both a main tin layer and a copper tin intermetallide layer in the processes involved for removing tin. In these conditions the copper pickling rate should not be too high.

The next considerations should be taken into account; on the one hand the composition has to be rather aggressive for the goal achievement, on the other hand it should not be too aggressive in order to prevent the significant copper support material attack. Otherwise it can affect the current-carrying capacity of a printed circuit board and the covering adhesion for a nonconducting underlayer. It is impossible to create the solution of the kind without using corrosion inhibitors.

Modern technologies involve the two-stage process for removing the metal resist. At the first stage the tin layer is removed without affecting the intermetallide layer and the second stage involves removing the intermetallide layer. The two-stage process allows avoiding the problems related to the tin deposition irregularity minimizing the pickling of a copper conducting underlayer. The reliable performance of the printed circuit board depends on it eventually. Manufacturing companies of chemicals for making printed circuit boards, as a rule, offer compositions for both steps of the stage described above [1]. 
The goal of the research has been to investigate properties of the nitric acid pickling solution with corrosion inhibitors for removing the tin metal resist from the copper conductor surface of printed circuit boards, the solution being characterized by the high selectivity in pickling tin as compared to copper.

\section{Experimental}

The rate of solving the tin and copper was determined by gravimetric method in using copper plate samples of $50 \mathrm{~cm}^{2}$ in area with appropriate coating of $8-10 \mu \mathrm{m}$ thickness by means of analytical balance "SARTOGOSM" CE224-C. The copper foil was tin-coated electrochemically. The direct potentiometry method was used for determining hydrogen ion activity. The solution acidity was determined by means of $\mathrm{pH}-$ meter "Akvilon" using pH-410 ESK-10601/7 glass electrode. Specific quantity of the metal involved was determined in the following way. The fixed metal tin sample was solved completely in the pickling solution of the certain volume, the solution density being measured by using aerometer. The tin and copper concentrations in the pickling solutions were determined by using X-ray fluorescence spectrometer SHIMADZU EDX-7000. The samples were photographed by using confocal laser microscope LEXT-OSL4100 (Olympus).

\section{Results and Discussion}

It is known from scientific publications that pickling solutions contain chemical substances having various properties. A number of components account for solving the metal resist; the others keep the stabilization of the metal compounds formed after pickling, it promoting the brilliance-forming and inhibiting process of solving the copper layer [2].

The dependence of the tin dissolution rate on the solution acidity was examined for the following solution composition; $x \mathrm{HNO}_{3}+5 \% \mathrm{NH}_{4} \mathrm{NO}_{3}+$ addition agents, $x$ varying over the range 10 to $30 \%$. The $8 \mu \mathrm{m}$ tin layer was found to be solved completely on the intermetallide copper underlayer in 90 seconds in solutions containing nitric acid in the range of $20-30 \%$. Kinetics of solving tin in nitric acid is of hydrogen ion reaction first order (Figure 1).

The partial substitution of nitric acid for methane sulfonic acid (MSA) does not result in changing the rate of dissolving tin significantly. The decrease in dissolution rate by $20 \%$ can be observed for the first 5-10 seconds (Figure 2).

One of the important process-dependent parameters of the pickling solution is the specific metal content, it allowing one to judge operability of the solution. In the present case the specific metal content is taken as the amount of dissolved metal tin grams in one litre of the pickling solution that does not result in forming final tailings in the solution. Dependence of density change of pickling solution composition on the amount of the tin solved in the solution was examined in that respect. Table 1 shows the results of studying the specific metal content for some solutions. 


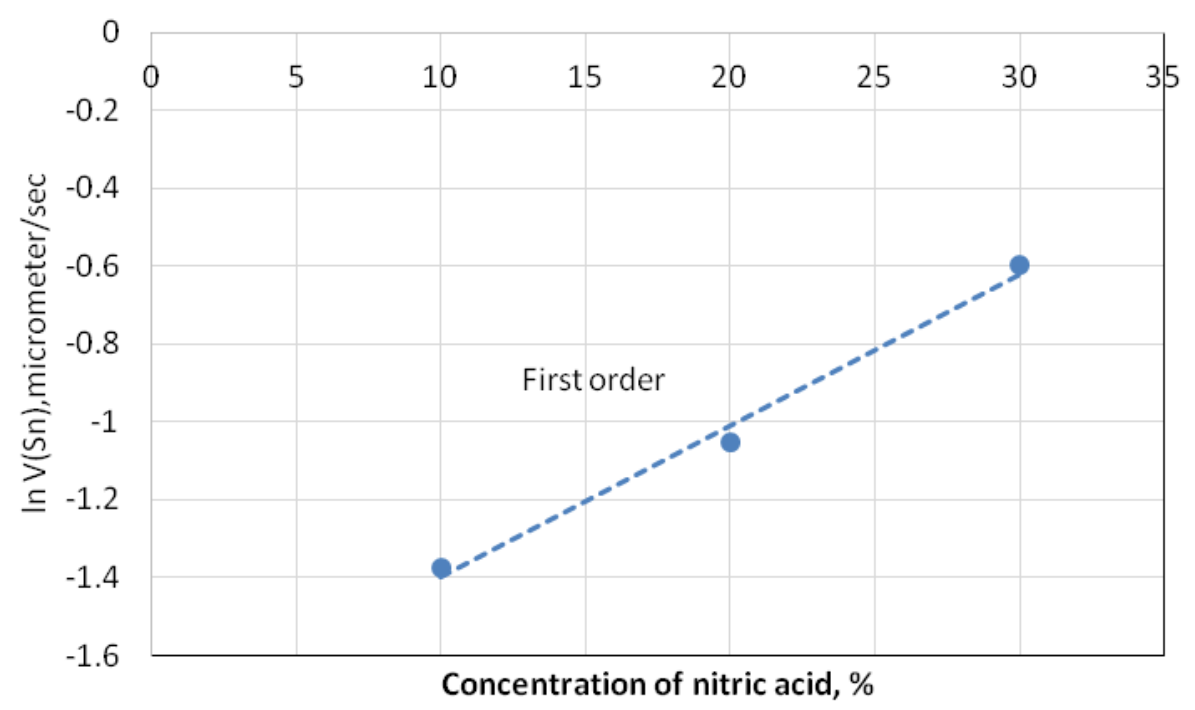

Figure 1. Dependence of $\ln \left(V_{\mathrm{Sn}}\right)$ on nitric acid concentration.

solution: $25 \mathrm{HNO}_{3}+5 \mathrm{MSA}+5 \mathrm{NH}_{4} \mathrm{NO}_{3}+3$ glycolic acid

solution: $20 \mathrm{HNO}_{3}+10 \mathrm{MSA}+5 \mathrm{NH}_{4} \mathrm{NO}_{3}+3$ glycolic acid

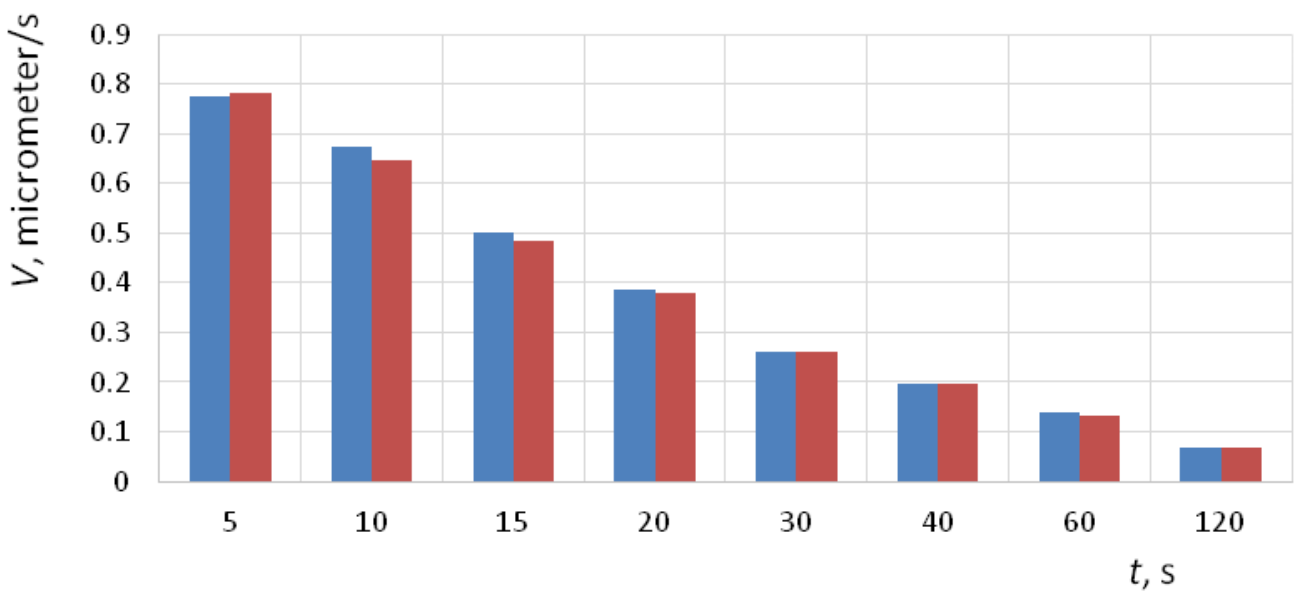

Figure 2. Dependence of tin dissolution rate on methane sulfonic acid concentration in the solution: $x \% \mathrm{HNO}_{3}+y \% \mathrm{MSA}+5 \% \mathrm{NH}_{4} \mathrm{NO}_{3}+$ addition agents. 
Table 1. Tin ion solution specific metal content.

\begin{tabular}{|c|c|c|}
\hline$\#$ & Solution composition & $\begin{array}{l}\text { Specific metal } \\
\text { content, Sn g/l }\end{array}$ \\
\hline 1 & $\begin{array}{c}\mathrm{HNO}_{3}-25 \%, \mathrm{NH}_{4} \mathrm{NO}_{3}-5 \%, \text { Glycolic acid }-2 \% \\
\text { Polyacrylamide }-1 \%\end{array}$ & 20 \\
\hline 2 & $\begin{array}{c}\mathrm{HNO}_{3}-25 \%, \mathrm{NH}_{4} \mathrm{NO}_{3}-5 \%, \text { Glycolic acid }-2 \% \\
\text { Acrylic acid }-2 \%\end{array}$ & 30 \\
\hline 3 & $\begin{array}{c}\mathrm{HNO}_{3}-25 \%, \mathrm{NH}_{4} \mathrm{NO}_{3}-5 \%, \text { Glycolic acid }-2 \% \\
\text { Trilon B }-1 \%\end{array}$ & 50 \\
\hline 4 & $\begin{array}{c}\mathrm{HNO}_{3}-25 \%, \mathrm{NH}_{4} \mathrm{NO}_{3}-5 \%, \text { Glycolic acid }-2 \% \\
\text { Hydroquinone }-1 \%\end{array}$ & 50 \\
\hline 5 & $\begin{array}{l}\mathrm{HNO}_{3}-25 \%, \mathrm{NH}_{4} \mathrm{NO}_{3}-5 \% \text {, Glycolic acid }-2 \% \\
\text { Polyvinylpyrrolidone }(\mathrm{Mr}=8000 \mathrm{~g} / \text { mole })-1 \%\end{array}$ & 30 \\
\hline 6 & $\begin{array}{l}\mathrm{HNO}_{3}-25 \%, \mathrm{NH}_{4} \mathrm{NO}_{3}-5 \% \text {, Glycolic acid }-2 \% \\
\text { EDTA (ethylenediaminetetraacetic acid) }-1 \%\end{array}$ & 20 \\
\hline 7 & $\begin{array}{c}\text { MSA }-25 \%, \mathrm{HNO}_{3}-5 \%, \mathrm{NH}_{4} \mathrm{NO}_{3}-5 \% \\
\text { Glycolic acid }-2 \%\end{array}$ & 140 \\
\hline 8 & $\begin{array}{c}\mathrm{HNO}_{3}-27 \%, \mathrm{NH}_{4} \mathrm{NO}_{3}-5 \%, \text { Glycolic acid }-2 \% \\
\text { Thiourea }-0.1 \% \text {, Sodium acetate }-1 \% \text {, Ethanol }-1 \% \\
\text { Benzotriazole }-0.1 \%\end{array}$ & 80 \\
\hline 9 & $\begin{array}{c}\mathrm{HNO}_{3}-27 \%, \mathrm{NH}_{4} \mathrm{NO}_{3}-5 \%, \text { Glycolic acid }-2 \% \\
\text { Thiourea }-0.1 \%, \text { Ethanol }-1 \% \text {, Benzotriazole }-0.1 \% \\
\text { Chloroacetic acid }-1 \%, \text { Trichloracetic acid }-1 \% \text {, Sodium acetate }-1 \%\end{array}$ & 60 \\
\hline 10 & $\begin{array}{c}\mathrm{HNO}_{3}-30 \%, \mathrm{NH}_{4} \mathrm{NO}_{3}-5 \% \text {, Glycolic acid }-2 \% \\
\text { Benzotriazole }-0.1 \%, \mathrm{NaCl}-2 \%, \mathrm{Cu}\left(\mathrm{NO}_{3}\right)_{2}-0.01 \%\end{array}$ & 210 \\
\hline
\end{tabular}

The table shows that the pickling solution \#10 containing $2 \%$ sodium chloride is of the most specific metal content.

The pickling solution allowing one to solve the intermetallide tin-copper layer was investigated in the solution of the following composition: $x \% \mathrm{HNO}_{3}+5 \% \mathrm{Fe}\left(\mathrm{NO}_{3}\right)_{3}+$ $1 \%$ Glycolic acid $+0.1 \%$ Benzotriazole, $x$ varying over the range 5 to $20 \%$. The thickness of the intermetallide tin-copper layer on printed circuit boards being usually less than 0.2 micrometer, we made the layer form artificially by burning the copper electrode coated with 3 micrometer tin layer in the oven at the temperature of $215^{\circ} \mathrm{C}$ for 5 hours, after that it was pickled in the solution involved (Figure 3). 


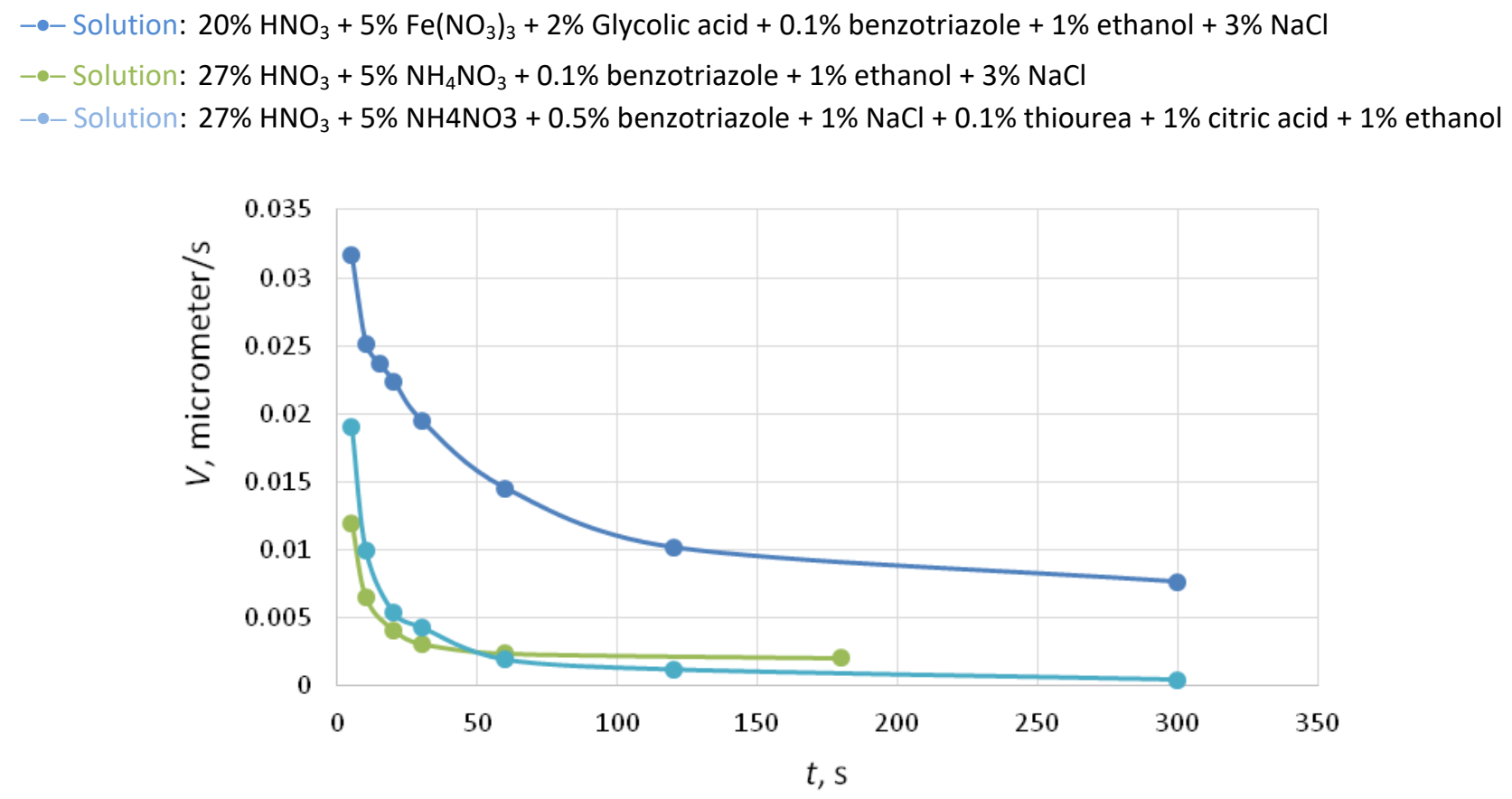

Figure 3. Pickling rate of the intermetallide in various solutions.

The intermetallide dissolution rate drops 3-4 times for the first 60 seconds of dissolving. Then it changes moderately to $0.075 \mu \mathrm{m} / \mathrm{s}$ value for the iron nitrate solution and to $0.002 \mu \mathrm{m} / \mathrm{s}$ value for the ammonium nitrate solution correspondently.

Table 2 shows the experimental results for the specific metal content of solutions for pickling the tin copper intermetallide layer.

Table 2. Tin ion solution specific metal content.

\begin{tabular}{|c|c|c|}
\hline \# & Solution composition & Specific metal content, Sn g/l \\
\hline 1 & $\begin{array}{l}\text { MSA }-15 \%, \mathrm{HNO}_{3}-5 \%, \mathrm{Fe}\left(\mathrm{NO}_{3}\right)_{3}-5 \% \text {, } \\
\text { Glycolic acid - } 1 \% \text {, Benzotriazole }-0.1 \%\end{array}$ & 40 \\
\hline 2 & $\begin{array}{c}\mathrm{HNO}_{3}-20 \%, \mathrm{Fe}\left(\mathrm{NO}_{3}\right)_{3}-5 \%, \text { Glycolic acid }-2 \% \\
\text { Benzotriazole }-0.5 \%, \mathrm{NaCl}-1 \%\end{array}$ & 55 \\
\hline
\end{tabular}

So, the partial substitution of nitric acid for methane sulfonic acid (MSA) does not allow increasing the specific metal content of solutions significantly.

One of the most important parameters of the solution for pickling the tin copper intermetallide layer is the capacity to avoid picking the copper plated circuit board underlayer. The influence of various inhibitors on the rate of dissolving the copper plated circuit board underlayer was examined to that end (Figure 4). 
$-\bullet 20 \% \mathrm{HNO}_{3}+5 \% \mathrm{Fe}\left(\mathrm{NO}_{3}\right)_{3}+2 \%$ Glycolic acid $+0.002 \%$ mercaptobenzothiazole

$-\bullet 20 \% \mathrm{HNO}_{3}+5 \% \mathrm{Fe}\left(\mathrm{NO}_{3}\right)_{3}+3 \%$ Glycolic acid $+0.1 \%$ nitrobenzimidazole

$20 \% \mathrm{HNO}_{3}+5 \% \mathrm{Fe}\left(\mathrm{NO}_{3}\right)_{3}+3 \%$ Glycolic acid $+0.5 \% \mathrm{NaCl}+0.5 \%$ benzotriazole

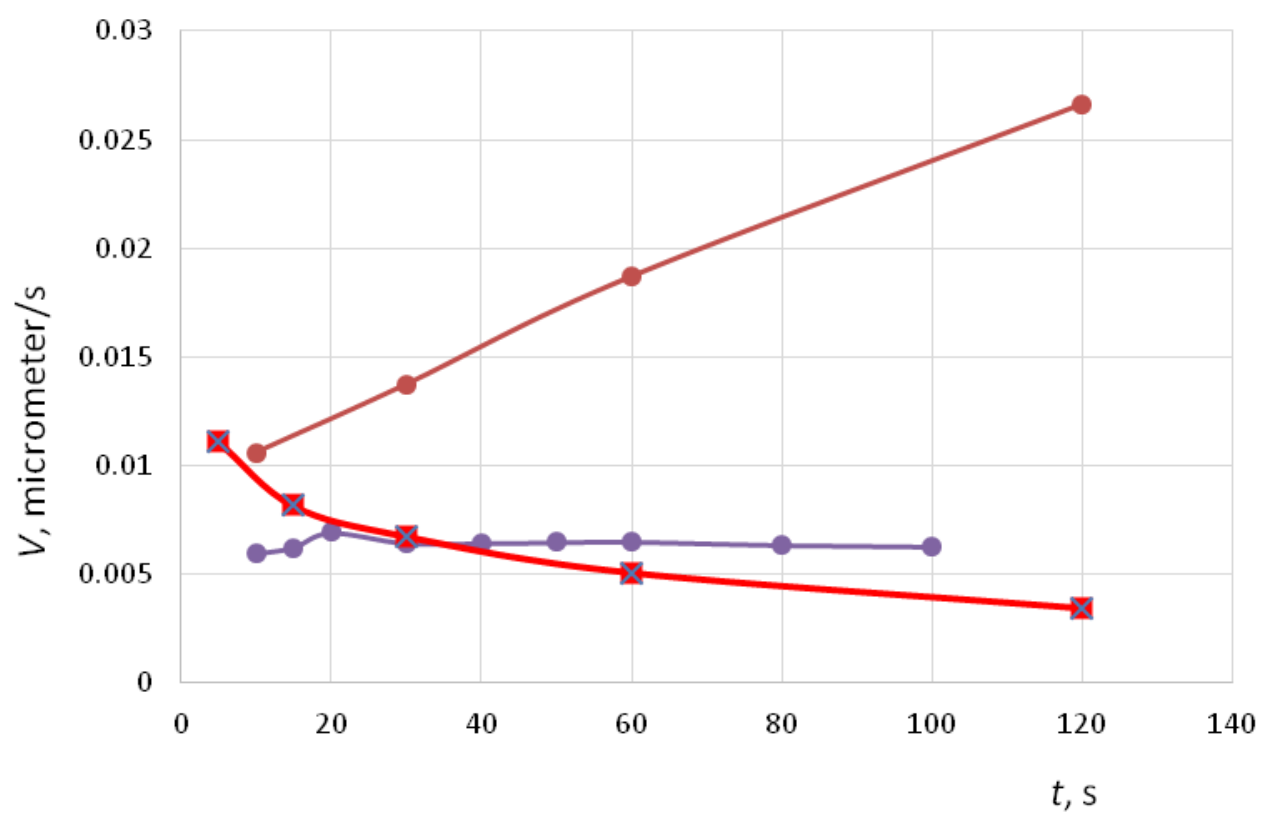

Figure 4. The rate of picking copper in various solutions.

The figure shows that the lowest rate of solving copper takes place in the solutions containing benzotriazole inhibitors and nitrobenzimidazole inhibitors, the rate value being $0.003-0.005 \mu \mathrm{m} / \mathrm{s}$. Benzotriazole can be used in pickling solution composition taking in consideration that nitrobenzimidazole is much more expensive than benzotriazole.

The important problem is the solution stability at different temperatures, the local solution heating being possible to take place in adding concentrated $68 \%$ nitric acid into water. In addition, temperature conditions can change considerably during transit. The solutions investigated were found to be stable over the range $18^{\circ} \mathrm{C}$ to $70^{\circ} \mathrm{C}$.

Figures 5, 6, 7 show electronic photographs of samples after consecutive pickling in nitric acid solutions containing ammonium nitrate salts and iron nitrate salts (III).

The photographs of the samples show that the bright pure copper underlayer without any spots forms after two-stage pickling tin coatings.

So, pickling nitric acid solution compositions with special addition agents are developed for the two-stage selective removing of tin metal resist. 


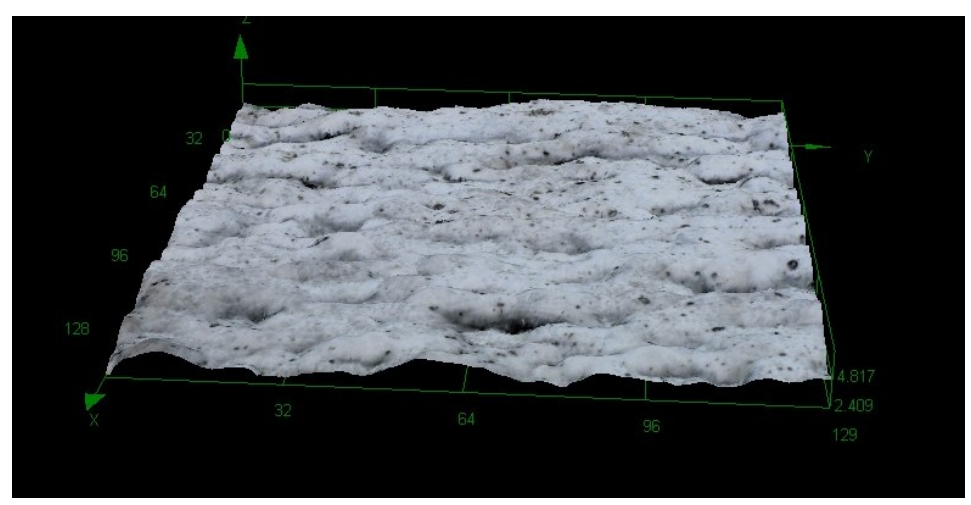

Figure 5. The tin coating before pickling; the image size is $129 \times 129 \mu \mathrm{m}$.

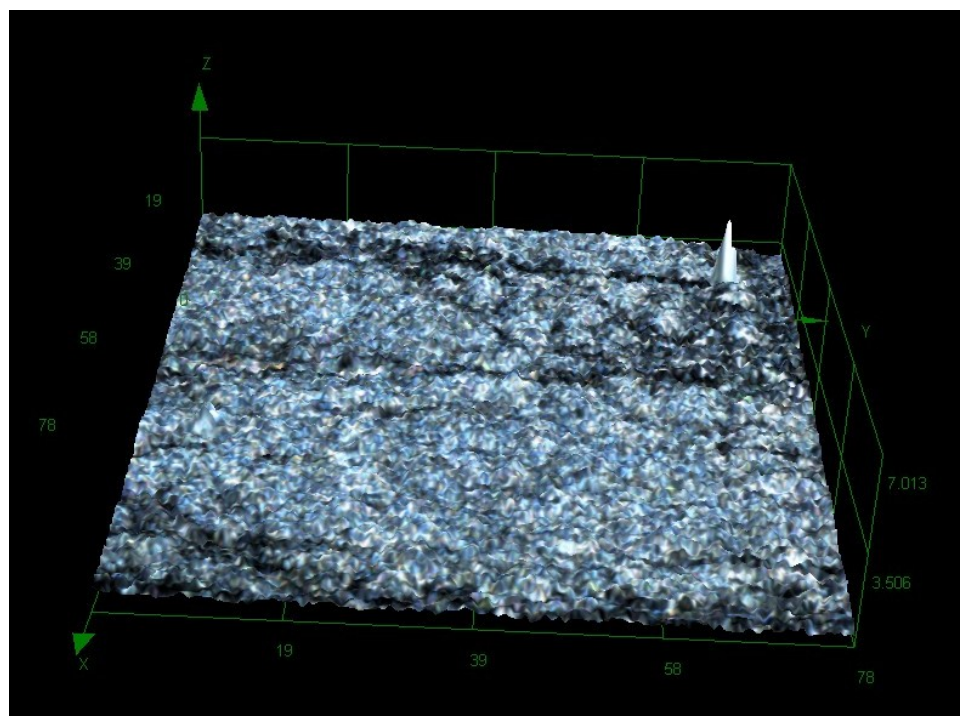

Figure 6. The intermetallide layer surface after pickling in the nitric acid containing ammonium nitrate salts; the image size $78 \times 78 \mu \mathrm{m}$.

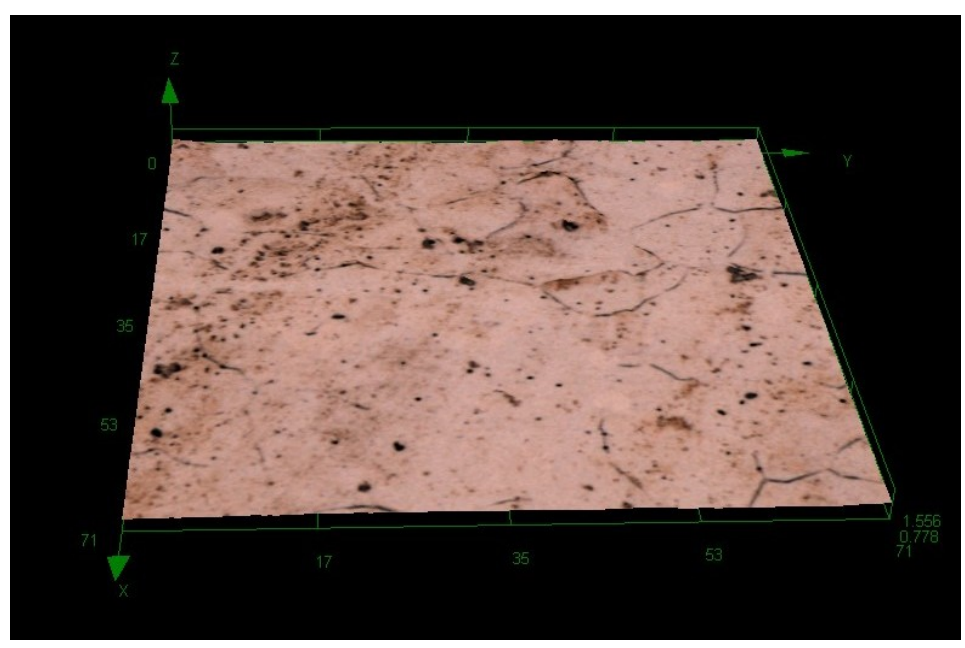

Figure 7. The copper conductor surface after intermetallide pickling in the nitric acid containing ammonium iron salts; the image size $71 \times 71 \mu \mathrm{m}$. 


\section{Conclusions}

Relatively selective pickling nitric acid solutions used with special addition agents are developed and studied, they removing galvanic tin from copper conductors of printed circuit boards effectively. The pickling solution composition can be density-modified by adding a fresh pickling solution.

\section{References}

1. S. Cambell, Composition and method for stripping tin and tin-lead from copper surfaces, U.S. Patent No. 5,911,907.

2. J. Jokinen, D.O. Trambitas, R. Penners and G.-J. Witkamp, A method for precipitating metal oxides from an aqueous waste solution, EC Patent WO2007042611 A1. 